\author{
Wiesław Block OFMCap ${ }^{1}$ \\ 0000-0003-4856-4035
}

Papieski Uniwersytet Antonianum, Rzym

\title{
Doświadczenie Alwerni źródłem powstania Drogi duszy do Boga św. Bonawentury z Bagnoregio
}

W uroczystość Zesłania Ducha Świętego, 23 maja 1260 roku rozpoczęła się, trzynasta po śmierci bł. Franciszka z Asyżu, kapituła generalna Braci Mniejszych. Miejscem spotkania minorytów było miasto Narbona, położone w południowej Francji nad pięknie wijącą się rzeką Aude. Bonawentura z Bagnoregio, jako minister generalny, wybrany na poprzedniej kapitule sprawowanej w Rzymie w lutym 1257 roku, podróżował pieszo po całej Europie wypełniając obowiązki związane z urzędem, który mu został przekazany. Na początku stycznia 1259 roku głosił kazania w Paryżu, na wiosnę udał się do Flandrii i Niemiec, w lipcu przewodniczył

1 Wiesław Block OFMCap - dr hab., prof. PUA w Rzymie, wykładowca we Franciszkańskim Instytucie Duchowości przy Papieskim Uniwersytecie Antonianum w Rzymie. Autor publikacji w języku polskim i włoskim o tematyce związanej z rozwojem duchowości św. Franciszka z Asyżu i ruchu minoryckiego w XIII i XIV wieku. Z ważniejszych prac można wymienić: Połowie mej duszy. Komentarz do listów św. Klary z Asyżu, Kraków 2006; Ikona św. Klary z Asyżu. Symbolika i duchowość, wraz z R. Rapacz, Kraków 2011; Vivere il vangelo con Francesco d'Assisi. Temi e figure della fraternità minoritica, Bologna 2013; Wszystkim chrześcijanom. Duchowość Franciszka z Asyżu w świetle jego pism, t. 1: Łaska początków, Kraków 2013, t. 2: Pierwotna intuicja, Kraków 2015 i t. 3: Idąc jego śladami, Kraków 2017. E-mail: wieslawb112@gmail.com. 
kapitule prowincjalnej we Francji w Saint-Omer, a już dwa tygodnie później nauczał w Arras, po czym pod koniec lata udał się do Włoch. Niedługo przed uroczystością Serafickiego Ojca (4 października) przebywał na Alwerni. Tutaj oddał się upragnionej medytacji i modlitwie. Owocem tej wydłużonej refleksji stało się dzieło Itinerarium mentis in Deum, czyli Droga duszy do Boga $a^{2}$, jak podkreślają znawcy przedmiotu - jeden z najważniejszych traktatów z zakresu teologii duchowości, jaki kiedykolwiek zrodził się $\mathrm{w}$ łonie zachodniego chrześcijaństwa³. Bonawentura nie poprzestał tylko na tym traktacie, bowiem w tym czasie, tzn. na przełomie 1259 i 1260 roku, powstały jeszcze inne dzieła z zakresu teologii duchowości czy życia wewnętrznego takie, jak: De triplici via (lub Incendium amoris), Soliloquium de quattuor mentalibus exercitiis, De quinque festivitatibus pueri Jesu, Tractatus de praeparatione ad missam, De perfectione vitae ad sorores i Lignum vitae ${ }^{4}$. Czas duchowego odpoczynku nie trwał jednak długo, już na początku 1260 roku minister generalny powrócił do Francji, biorąc czynny udział w przygotowaniach do kapituły generalnej ${ }^{5}$.

\section{Alwernia, miejsce powstania traktatu}

Traktat Droga duszy do Boga - podstawowy przedmiot zainteresowania tego artykułu - jest bez wątpienia wyrazem nowej duchowości, jaka wraz z osobą Franciszka z Asyżu stała się żywotną częścią życia Kościoła

2 Polski przekład tekstu, do którego odwołuję się w niniejszym studium, to: Święty Bonawentura, Droga duszy do Boga i inne traktaty, przeł. C. Niezgoda, S. Kafel, Poznań 2001. Tekst łaciński znajduje się w: S. Bonaventurae, Itinerarium mentis in Deum, w: S. Bonaventurae, Opuscula varia. Theologica, t. 5, Quaracchi 1891, s. 293-316.

3 Łaciński tytuł dzieła - Itinerarium mentis in Deum - trudno oddać w języku polskim. Pierwsze słowo bez wątpienia oznacza drogę, przejście, pielgrzymkę. Z kolei wyrażenie mens (-tis) w języku Bonawentury odnosi się nie tylko do duszy czy umysłu, co do całego człowieka. Uwidacznia to choćby niemiecki przekład tytułu: Der Weg des Menschen zu Gott.

4 Teksty związane z teologią mistyczną i życiem duchowym Bonawentury zostały opublikowane w Opera omnia, VIII, 1-229. Ponadto ukazały się one również w osobnym dziele: Decem opuscula ad theologiam mysticam spectantia, Quaracchi 1896, 19655; wymienione pisma mistyczne św. Bonawentury zostały przełożone na język polski i są wydane drukiem: św. Bonawentura, Pisma ascetyczno-mistyczne, Warszawa 1984.

5 Por. F. Corvino, Bonaventura da Bagnoregio, francescano e pensatore, Bari 2006, 144-175. 
katolickiego. Autor traktatu, Bonawentura z Bagnoregio, umiejętnie połączył w jedno dziedzictwo duchowości franciszkańskiej, refleksję teologiczno-filozoficzną Kościoła wraz ze swym osobistym doświadczeniem życia wewnętrznego ${ }^{6}$. Powstanie dzieła powiązane jest $\mathrm{z}$ jego pobytem na górze Alwerni, miejscu szczególnym, bo uświęconym stygmatyzacją Serafickiego Ojca. Bez wątpienia jedyna w swoim rodzaju atmosfera tej pustelni i gęsto zalesionej góry, na której po raz pierwszy człowiek dostąpił łaski duchowego i fizycznego upodobnienia się do Wcielonego Boga, dała warunki sprzyjające medytacji. Jej owocem stał się duchowy przewodnik (itinerarium) dedykowany tym, co noszą w swym sercu pragnienie dążenia ku Bogu. Generał zakonu we wstępie do swego dzieła podkreśla znaczenie tego miejsca i ofiarowuje swemu czytelnikowi opis wewnętrznych przeżyć, jakie stały się jego udziałem:

Ja, grzesznik, w 33 roku życia, kiedy byłem (ze wszech miar niegodnym) siódmym generałem zakonu, po śmierci błogosławionego ojca Franciszka, za jego przykładem poszukiwałem pokoju, do którego gorąco wzdychałem. Za Boskim natchnieniem, mniej więcej w czasie obchodzenia rocznicy śmierci błogosławionego, wiedziony tęsknotą za pokojem ducha, udałem się na górę Alwernię jako na miejsce wytchnienia ${ }^{7}$. Przebywając tam, rozważałem niektóre sposoby wznoszenia się naszego ducha ku Bogu. Między innymi przyszło mi na myśl owo cudowne zdarzenie, które właśnie tutaj przytrafiło się błogosławionemu Franciszkowi, mianowicie widzenie skrzydlatego serafina, który przypominał Ukrzyżowanego. Gdy to rozważałem, nagle uświadomiłem sobie, że widzenie przedstawiało kontemplacyjny zachwyt naszego ojca oraz wskazywało drogę, która do niego prowadzi ${ }^{8}$.

6 Dzieło Bonawentury jest bardzo bogate, jeśli chodzi o idee i myśli w nim wykorzystane. Odwołuje się ono bez wątpienia do tradycji neoplatońskiej, głównie do takich autorów jak: Augustyn z Hippony, Teodozjusz Makrobiusz i Pseudo-Dionizy oraz do pojęć i wyrażeń typowych dla języka późnej scholastyki.

7 W tym miejscu tłumaczenie wydaje się odbiegać od oryginału. Tekst łaciński brzmi bowiem następująco: „Cum igitur exemplo beatissimi patris Francisci hanc pacem anhelo spiritu quaererem, ego peccator, qui loco ipsius patris beatissimi post eius transitum septimus in generali fratrum ministerio per omnia indignus succedo; contigit ut nutu divino circa Beati ipsius transitum, anno trigesimo tertio (1259) ad montem Alvernae tanquam ad locum quietum amore quaerendi pacem spiritus declinarem [...]”. Wydaje się zatem, iż właściwszy byłby następujący przekład: „Za przykładem błogosławionego Ojca Franciszka poszukiwałem pokoju, do którego mocno wzdychałem. Ja grzesznik, ze wszech miar niegodny, siódmy generał zakonu, trzydzieści trzy lata po jego śmierci, za boskim natchnieniem, udałem się na górę Alwernię (1259) [...]”.

8 Itinerarium, Prolog 2. 
Franciszek z Asyżu ponad trzydzieści lat wcześniej, właśnie na tej górze we wrześniu 1224 roku, po tym jak ujrzał Serafina, został odznaczony na rękach, stopach i prawym boku znakami męki Pańskiej. Franciszkowe doświadczenie, rozważane przez Bonawenturę, stało się źródłem nie tylko co do treści powstającego traktatu, ale także co do jego struktury. Doktor Seraficki zrozumiał, że podobnie jak Seraficki Ojciec, każdy chrześcijanin może, poczynając od kontemplacji śladów Boga widocznych w makrokosmosie, przejść do kontemplacji obrazu Boga w mikrokosmosie (duszy), by następnie w ostatnim etapie duchowego rozwoju wraz z ukrzyżowanym Chrystusem dojść do doświadczenia Boga Trójjedynego w łasce wlanej ekstazy. Natomiast wizja Serafina o sześciu skrzydłach - zgodnie z biblijnym opisem ułożonych w trzy pary po dwa (por. Iz 6, 1-2) ${ }^{9}$ - posłużyła Bonawenturze jako model co do schematu podziału drogi ku Bogu na sześć etapów, w trakcie których dusza człowieka (mens) staje się oświecona Bożym światłem (illuminationum suspensiones):

Sześć skrzydeł można poprawnie rozumieć jako sześć zachwytów iluminacji, dzięki którym dusza, jak gdyby przeszedłszy sześć stopni czy dróg, otrzymuje zdolność dojścia do pokoju na drodze ekstatycznych zachwytów chrześcijańskiej mądrości ${ }^{10}$.

Bonawentura podkreśla też wyraźnie już we wstępie do swego dzieła: „Moje rozważanie poświęcam tym, których nawiedziła łaska Boża, pokornym i miłosiernym, skruszonym i pobożnym, namaszczonym «olejkiem wesela» (Ps 44,8), rozmiłowanym w Bożej mądrości, płonącym jej pragnieniem, gotowym poświęcić się dla Boga jako tego, kto powinien być objawiony, podziwiany i kosztowany" (Itinerarium, Prolog 4).

9 „W roku śmierci króla Ozjasza ujrzałem Pana siedzącego na wysokim i wyniosłym tronie, a tren Jego szaty wypełniał świątynię. Serafiny stały ponad Nim; każdy z nich miał po sześć skrzydeł; dwoma zakrywał swą twarz, dwoma okrywał swoje nogi, a dwoma latał". ${ }^{10}$ Itinerarium, Prolog 3: „Nam per senas alas illas recte intelligi possunt sex illuminationum suspensiones, quibus anima quasi quibusdam gradibus vel itineribus disponitur, ut transeat ad pacem per exstaticos excessus sapientiae christianae". 


\section{Rola brata Leona}

Wczytując się w tekst traktatu, jak też przyglądając się innym pismom Bonawentury, dostrzega się jego dobrą znajomość tego, co wydarzyło się na Alwerni. Skąd generał zakonu mógł tak dobrze znać przebieg stygmatyzacji Franciszka? Ojcowie z Quaracchi, publikując już ponad sto lat temu krytyczne wydanie dzieł Bonawentury (Opera omnia), wskazują na jego list wysłany z Alwerni w październiku 1259 roku i adresowany do Ubogich Pań w Asyżu. W tym liście, Doktor Seraficki przedstawia samego siebie oraz nie ukrywa, iż słabo zna dzieje św. Klary i jej sióstr. Wspomina, iż informacje o ich życiu otrzymał od brata Leona z Asyżu, towarzysza świętego Ojca, którego niedawno spotkał, a który zgodnie z przekazem źródeł hagiograficznych był naocznym świadkiem stygmatyzacji ${ }^{11}$ :

Umiłowanym Córkom w Chrystusie Jezusie, Ksieni Ubogich Pań z Asyżu, z klasztoru świętej Klary i wszystkim jej Siostrom - brat Bonawentura, minister generalny i sługa Zakonu Braci Mniejszych przesyła życzenia zdrowia w pragnieniu podążania, wraz z błogosławionymi dziewicami gotowymi w oczekiwaniu, za Barankiem, dokądkolwiek się uda. Niedawno dowiedziałem się, umiłowane Córki w Panu, od naszego drogiego brata Leona, towarzysza świętego Ojca, że staracie się usilnie służyć Chrystusowi ubogiemu i ukrzyżowanemu, w całkowitej czystości, jako oblubienice wiecznego Króla, z czego raduję się bardzo w Panu (List z Alwerni, październik 1259) ${ }^{12}$.

Być może, iż brat Leon był w tym czasie kapelanem wspólnoty Ubogich Pań w San Damiano ${ }^{13}$. W każdym razie, choć list nie wspomina o tym

11 Więcej na temat brata Leona z Asyżu w: W. Block, Franciszek i jego bracia, tłum. K. Kreczko, Kraków 2017, s. 129-153.

12 „Intelligens nuper, dilectae in Domino filiae, per carissimum nostrum fratrem Leonem, quondam socium sancti Patris, quomodo velut sponsae Regis aeterni servire Christo pauperi crucifixo in omni puritate studeatis", S. Bonaventurae, Opusculum XIX. Epistole officiales. Epistola VII, w: Opera omnia, Quaracchi 1898, VIII, s. 473-474; por. włoskie tłumaczenie w: S. Chiara d'Assisi. Scritti e documenti, a cura di G. G. Zoppetti e M. Bartoli, Assisi 1994, 422.

13 Por. E. Menestò, Leone e i compagni di Assisi, w: I compagni di Francesco e la prima generazione minoritica. Atti del XIX Convegno internazionale della S.I.S.F (Assisi, 17-19 ottobre 1991), pod red. E. Menestò, Spoleto 1992, 44-51; Bartoli Langeli uważa, że Leon nigdy nie był kapelanem Klarysek, por. A. Bartoli Langeli, Gli autografi di frate Francesco e di frate Leone, Turnhout 2000, 95 (Corpus Christanorum. Autographa Medii Aeui, V). 
bezpośrednio, jest bardzo prawdopodobnym, że to właśnie on przedstawił ministrowi generalnemu pergamin (chartula), jaki otrzymał od Franciszka na górze Alwerni, zaraz po tym, jak Święty otrzymał stygmaty ${ }^{14}$. Franciszek stygmatyzowaną dłonią na stronie zdrowej (odmięsnej) pergaminu zapisał laudę Uwielbienie Boga Najwyższego, a na stronie licowej (od strony sierści) Błogosławieństwo dla brata Leona, w którym wykorzystując biblijny tekst błogosławieństwa Aaronowego (por. Lb 6, 24-26), błogosławił swemu towarzyszowi. Pergamin, z racji na to, że powstał w tak niewiarygodnych okolicznościach, nierzadko był traktowany niczym potężna i magiczna relikwia: „Pismo [...] w przyszłości sprawiło rzeczy godne podziwu" (Mem 49). Dzisiaj owa chartula przechowywana jest w kaplicy relikwii w Sacro Convento w Asyżu. Chartula prócz tekstu zapisanego czarnym atramentem przez brata Franciszka zawiera trzy dodatki zapisane na czerwono, tzw. rubryki lub glossy. Trudno wskazać dokładną datę powstania tych rubryk. Większość badaczy widzi jako terminus post quem 16 lipca 1228 roku, dzień kanonizacji Franciszka, a jako terminus ante quem 11 sierpnia 1246 roku, data powstania tzw. Listu z Greccio ${ }^{15}$. Włoska historyk średniowiecza Chiara Frugoni twierdzi, iż dopiski mogły powstać pomiędzy 1257 a 1258 rokiem, przy okazji przekazania Brewiarza św. Franciszka przez brata Leona i brata Anioła opatce Ubogich Pań, o imieniu Benedykta ${ }^{16}$. Same rubryki zostały napisane dojrzałą kaligra-

14 O tym fakcie wspomina brat Tomasz z Celano w Memoriale (dalej: Mem.): „Kiedy Święty przebywał na górze Alwernia, zamknięty w celi, jeden z jego towarzyszy bardzo pragnął mieć krzepiące pismo ku czci Pana, skreślone krótko ręką świętego Franciszka. Wierzył bowiem, że za pomocą tego pisma wyjdzie cało albo przynajmniej mniej ucierpi od ciężkiej pokusy, jaka go dręczyła, pokusy nie ciała, lecz ducha. Męczyło go to pragnienie, ale bał się wyjawić je otwarcie świętemu Ojcu. Lecz to, czego nie powiedział mu człowiek, objawił Duch. Pewnego dnia Franciszek zawołał go, mówiąc: «Przynieś mi kartę i atrament, ponieważ chcę napisać słowa Pańskie i Chwalby, jakie rozważyłem w sercu swoim». Szybko przyniósł mu, o co prosił, a Święty napisał własnoręcznie Chwalby Pana i słowa, jakie chciał, a na końcu błogosławieństwo dla brata. Powiedział: «Weź sobie tę kartę i pilnie strzeż jej aż do dnia swej śmierci». Zaraz ustąpiła wszelka owa pokusa; pismo zostało zachowane i w przyszłości sprawiło rzeczy godne podziwu" (Mem. 49).

15 Por. G. Miccoli, Francesco d'Assisi. Memoria, storia e storiografia, Milano 2010, s. 281-298 (Edizioni Biblioteca Francescana, 12).

16 Por. C. Frugoni, Francesco e l'invenzione delle stimmate: una storia per parole e immagini fino a Bonaventura e Giotto, Torino 1993, s. 76. 
fią przez człowieka w wieku między czterdzieści pięć a sześćdziesiąt lat: „jest to pismo świadczące o znacznych umiejętnościach i kompetencjach piszącego, jak przystało na duchownego, jakim był Leon; jest to pismo semigotyckie, książkowe"17. Brzmienie trzech rubryk jest następujące: Rubryka pierwsza (u góry pergaminu)

Błogosławiony Franciszek na dwa lata przed swoją śmiercią odprawiał na Alwerni czterdziestodniowy post ku czci Błogosławionej Dziewicy, Matki Boga i Błogosławionego Michała Archanioła od święta Wniebowzięcia Świętej Maryi Dziewicy do święta świętego Michała we wrześniu; i spoczęła na nim ręka Pańska; po widzeniu i przemówieniu Serafina i wyrażeniu się stygmatów na jego ciele ułożył te uwielbienia napisane na drugiej stronie kartki i własną ręką napisał, dziękując Bogu za dobrodziejstwo mu wyświadczone ${ }^{18}$.

Rubryka druga (w środkowej części pergaminu):

Błogosławiony Franciszek napisał własną ręką to błogosławieństwo dla mnie, brata Leona ${ }^{19}$.

Trzecia rubryka (u dołu pergaminu):

W ten sam sposób własną ręką uczynił ten znak Tau z głowąa ${ }^{20}$.

Minister generalny miał przynajmniej dwie możliwości, by spotkać brata Leona przed swoim pobytem na Alwerni. Pierwsza z nich była w 1257 roku w maju, kiedy przybył do Włoch, by przedstawić się papieżowi Aleksandrowi IV. Kardynał Rinaldo Conti został wybrany na papieża 12 grudnia 1254 roku i oprócz wielu funkcji, jakie wcześniej sprawował, był także protektorem Zakonu Braci Mniejszych. Jako papież

17 A. Bartoli Langeli, Gli autografi, s. 89, tłum. z wł., cytuje: W. Block, Franciszek i jego bracia, dz. cyt., s. 144.

18 „Beatus Franciscus duobus annis ante mortem suam fecit quadragesimam in loco Alverne, ad honorem beate Virginis Matris Dei et beati Michaelis Archangeli, a festo Assumptionis sancte Marie Virginis usque ad festum sancti Michaelis septembris; et facta est super eum manus Domini. Post visionem et allocutionem Seraphim et impressionem stigmatum Christi in corpore suo, fecit has laudes ex alio latere cartule scriptas et manu sua scripsit, gratias agens Deo de beneficio sibi collato". Łacińska wersja tekstu na podstawie wyd. krytycznego pod red.: C. Paolazzi, Scritti di Francesco d'Assisi, Grottaferrata 2009, s. 116.

19 „Beatus Franciscus scripsit manu sua istam benedictionem michi fratri Leoni”.

20 "Simili modo fecit istud signum thau cum capite, manu sua". 
niejednokrotnie wyrażał swe zadowolenie z wyboru Bonawentury na ministra generalnego i aprobatę dla jego poczynań, jak na to wskazuje choćby list napisany 21 października 1257 roku $^{21}$. Druga, o wiele bardziej prawdopodobna, data spotkania się z bratem Leonem to 1259 rok. Bonawentura mógł go widzieć, zanim udał się na Alwernię, bowiem w liście wysłanym do sióstr z San Damiano wspomina, iż „niedawno dowiedział się" na ich temat. Kiedy Bonawentura w kilka lat później rozpoczął pisanie Żywota błogosławionego Franciszka, tzw. Legendę większą, bez wątpienia wykorzystał informacje otrzymane od brata Leona, jak na to wskazuje sam tekst i podobieństwa z opisem obecnym na chartuli:

Tak więc na dwa lata przed oddaniem ducha niebu, po przeróżnych trudach, przez Bożą Opatrzność został zaprowadzony na górę wysoką, osobno, która zwie się Alwernia. Gdy według swego zwyczaju rozpoczął czterdziestodniowy post na cześć świętego Michała Archanioła, bardziej niż zwykle ogarnęła go słodycz Bożej kontemplacji i rozpalił większy płomień niebieskich pragnień. [...]. Któregoś ranka, około święta Podwyższenia Krzyża Świętego, podczas modlitwy na zboczu góry, zobaczył, że z wysokości niebios zstępuje jeden Serafin mający sześć ognistych i błyszczących skrzydeł. Kiedy bardzo szybkim lotem zbliżył się do męża Bożego i zawisł w powietrzu, pomiędzy skrzydłami ukazała się podobizna ukrzyżowanego człowieka, mającego ręce i nogi rozciągnięte na podobieństwo krzyża i do niego przybite (Legenda większa XIII 1, 4-5; 3, 2-3).

Pobyt w tak szczególnym miejscu, na Alwerni, a potem opis wydarzeń, z jakim Doktor Seraficki zapoznał, gdy czytał Chartulę i słuchał naocznego świadka wydarzeń, jakim był brat Leon, sprawiły, iż: „,nagle uświadomił sobie, że widzenie przedstawiało kontemplacyjny zachwyt naszego ojca

${ }^{21}$ Wspomniany list zawiera między innymi takie słowa: „Ażebyś, na chwałę Boga, mógł w sposób wolny i z większym autorytetem sprawować posługę Tobie powierzoną i żeby żaden brat twego zakonu nie mógł uchylić się w żaden sposób od regularnego zachowywania dyscypliny, czynimy absolutnym zakaz wobec każdego z ministrów prowincjalnych, kustoszy, gwardianów i innych braci mocą ślubu świętego posłuszeństwa, odwoływania się do przywilejów, listów i jakiegokolwiek rodzaju dyspens bez twego wyraźnego pozwolenia, jako że my zatwierdzamy nieodwołalnie, w imieniu Bożego autorytetu, jakąkolwiek karę, jaką uznasz za stosowną do wyznaczenia wobec tego, kto nie będzie posłuszny temu naszemu postanowieniu", cyt. za: E. Longpré, Bonaventure, w: Dictionnaire d'histoire et de geographie ecclesiastiaues (dalej: DHGE), t. 9, ed. A. Baudrillart, A. de Meyer, R. Aubert, Paris 1937, col. 756 (tłum. własne). 
oraz wskazywało drogę, która do niego prowadzi", jak sam o tym powie we wstępie do Itinerarium.

\section{Tomasz z Celano i Żywot błogosławionego Franciszka}

Biorąc pod uwagę strukturę tekstu Drogi duszy do Boga, można zauważyć, że Bonawentura nie był pierwszym autorem franciszkańskim, który wykorzystał alegorię skrzydeł Serafina. O stygmatyzacji i widzeniu Serafina o sześciu skrzydłach pisał już w 1229 roku w Żywocie błogosławionego Franciszka brat Tomasz z Celano ${ }^{22}$. Tomasz pochodzący z Abruzzo został poproszony o napisanie tego dzieła przez papieża Grzegorz IX, który przygotowując kanonizację i budując nową bazylikę na cześć nowego świętego, chciał jednocześnie wskazać wszystkim chrześcijanom wzór świętości, jaka zajaśniała w osobie brata Franciszka ${ }^{23}$. Tomasz z Celano po kapitule generalnej 1221 roku udał się pod wodzą brata Cezarego ze Spiry na misję do Niemiec, gdzie szybko został kustoszem Prowincji Reńskiej, zaledwie na dwa lata przed śmiercią Franciszka powrócił do Asyżu. Z pewnością był on obecny przy łożu śmierci stygmatyzowanego Franciszka, o czym świadczy dokładny opis jego śmierci zawarty w Żywocie (por. ŻbłF, 109-118). Nie był natomiast ani naocznym świadkiem, ani nie mógł słyszeć z ust Franciszka informacji co do wydarzeń, jakie miały miejsce na Alwerni we wrześniu 1224 roku. Na pewno jednym ze źródeł poznania przebiegu stygmatyzacji błogosławionego Franciszka był brat Leon, tak samo jak to miało miejsce w przypadku Bonawentury i wielu innych braci.

22 Więcej na temat brata Tomasza z Celano: W. Block, Franciszek i jego bracia, dz. cyt., s. $191-220$.

${ }_{23}$ Praca brata Tomasza postępowała bardzo szybko, tak że już w lutym, a najpóźniej przed 25 maja 1230 roku, czyli przed przeniesieniem ciała Franciszka do nowo wybudowanej bazyliki, Żywot błogosławionego Franciszka był gotowy. Kodeks 3817 znajdujący się w Bibliotece Narodowej w Paryżu informuje, że 25 II 1229 roku papież Grzegorz IX, który w tym czasie znajdował się w Perugii, „otrzymał, zatwierdził i zaaprobował” legendę napisaną przez brata Tomasza. Por. G. Miccoli, Dall'agiografia alla storia: considerazioni sulle prime biografie francescane come fonti storiche, w: Francesco d'Assisi. Realta e memoria di un esperienza cristiana, red. G. Miccoli, Torino 1991, s. 209. 
Żywot błogosławionego Franciszka został podzielony na trzy części (opuscula), poprzedzone krótkim Prologiem (por. ŻbłF 1-224. Opusculum secundum opisuje ostatnie dwa lata życia błogosławionego Franciszka i wydarzenia związane ze stygmatami. To właśnie tutaj po raz pierwszy franciszkańska literatura hagiograficzna opisuje wydarzenia z Alwerni, przedstawiając ich przebieg i widzenie Serafina ${ }^{25}$. Trzeci rozdział Dziełka drugiego, zatytułowany Widzenie człowieka o postaci ukrzyżowanego Serafi$n a^{26}$, brzmi następująco:

Kiedy pozostawał w pustelni, która od miejscowości, gdzie jest położona, zwie się Alwernia, na dwa lata zanim oddał duszę Bogu, ujrzał w widzeniu Bożym stojącego nad sobą mężczyznę, [jakby Serafina] ${ }^{27}$ mającego jakby sześć skrzydeł, z rękami wyciągniętymi, a z nogami złączonymi, przybitego do krzyża. Dwa skrzydła unosiły się nad głową, dwa wyciągały do lotu, dwa wreszcie okrywały całe ciało. Gdy święty sługa Najwyższego ujrzał to widzenie, jak najbardziej zadziwił się, ale nie wiedział, co ono miało dlań znaczyć. Bardzo się ucieszył i mocno uradował miłym i łaskawym względem, z jakim Serafin patrzył na niego. Jego piękno było niezwykle urzekające, ale całkowicie przejmowało trwogą jego przybicie do krzyża i udręczenie męką. Powstał więc, żeby tak powiedzieć, smutny i radosny zarazem, a radość i smutek na przemian brały w nim górę. Pilnie myślał, co by to widzenie mogło znaczyć, i duch jego bardzo trapił się uchwyceniem tego znaczenia. I gdy tak nic pewnego nie pojmował z tej wizji, a jej nowość ogromnie zajęła mu serce,

24 Pierwsza część dzieła (opusculum primum) opisuje życie Franciszka począwszy od dnia jego narodzenia aż do 25 grudnia 1223 roku, tj. osiemnastego roku jego nawrócenia (por. ŻbłF 3-87). Opusculum secundum przedstawia dwa ostatnie lata życia Stygmatyka i jego śmierć (por. ŻbłF 88-118). W opusculum tertium znalazł się opis wydarzeń zaistniałych po śmierci Franciszka wraz z dokładną relacją przebiegu beatyfikacji (por. ŻbłF 119-150). Całość dzieła kończył bardzo krótki Epilog (por. ŻbłF 151).

25 Por. W. Block, Franciszek Seraficki, Kraków 2013, s. 25-38 (Biblioteka Instytutu Studiów Franciszkańskich, 14).

26 Wprowadzeniem w lekturę trzeciego rozdziału są dwa poprzednie rozdziały. Rozdział pierwszy, nieoczekiwanie, został zbudowany według schematu bulli kanonizacyjnej Franciszka z Asyżu Mira circa nos! Odwołaniem się do tej bulli Celano rozpoczyna Dziełko drugie; przywołuje on konkretne obrazy tekstu papieskiego, jakby chciał w ten sposób nadać większą rangę swemu opisowi, a jednocześnie poprzez osobiste wzmianki i dopiski, jego relacja staje się o wiele bardziej szczegółowa niż ogólny przekaz zamieszczony w Mira circa nos, por. W. Block, Franciszek Seraficki, dz. cyt., s. 28.

${ }_{27}$ Niestety, polskie tłumaczenie tego tekstu zawarte w: Źródłach franciszkańskich z 2005 roku (s. 508) pomija wzmiankę o Serafinie, która jest obecna już w tym miejscu w łacińskiej wersji językowej: ,vidit in visione Dei virum unum, quasi Seraphim sex alas habentem, stantem supra se, manibus extensis ac pedibus coniunctis, cruci affixum", por. Fontes Franciscani, red. E. Menestò, S. Brufani i in., Assisi 1995, s. 370. 
oto na jego rękach i stopach zaczęły ukazywać się znamiona gwoździ, jak to krótko przedtem widział nad sobą u męża ukrzyżowanego (ŻbłF 94, 1-7) ${ }^{28}$.

Myśl brata Tomasza, po przekazaniu dokładnej relacji o stygmatyzacji Franciszka, kieruje się w następnych wersach tekstu ku interpretacji nowego cudu (por. ŻbłF 114, 6). Rozdział dziewiąty zatytułowany: Lament braci oraz radość ze stygmatów. Alegoria skrzydeł Serafina ${ }^{29}$, jest próbą wyjaśnienia znaczenia skrzydeł Serafina w kontekście cudu stygmatyzacji. Dla brata Tomasza sześć skrzydeł Serafina odnosi się głównie do cnoty miłości, cnoty, jaką cechuje się najwyższy spośród chórów anielskich, chór Serafinów. Owa miłość (miłość seraficka), stała się udziałem brata Franciszka. Jednak nie jest ona wyłączna tylko dla niego, każdy chrześcijanin - według brata Tomasza - może na wzór Serafickiego Ojca, wprowadzać ją w życie. Pierwszą cnotą na drodze ku doskonałej miłości, jaką proponuje brat Tomasz naśladowcom stygmatyzowanego Franciszka, jest czysta intencja: symbolizują ją dwa pierwsze skrzydła Serafina wyciągnięte ponad głową:

Możemy to bez wątpienia osiągnąć, jeśli jak Serafin wyciągniemy dwa skrzydła ponad głową, to znaczy, jeśli za wzorem świętego Franciszka w każdym dobrym uczynku będziemy mieć czystą intencję i prawe działanie, a niestrudzenie we wszystkim skierowując je do Boga, będziemy pragnęli podobać się tylko Jemu samemu. Aby nakryć głowę, te skrzydła muszą się koniecznie połączyć, ponieważ Ojciec świateł nie przyjąłby prawych uczynków bez czystej intencji i na odwrót (ŻbłF 114, 8-9).

${ }_{28}$ Powyżej cytowany fragment ma ogromne znaczenie dla historiografii, bowiem wraz z tym opisem język i duchowość franciszkańska zostały wzbogacone o nowy dwumian: Franciszek-Serafin. Począwszy od tego momentu pojęcie Franciszek-Serafin będzie zawsze związane z tym, co wydarzyło się we wrześniu 1224 roku na górze Alwerni, czyli ze stygmatyzacją błogosławionego Franciszka. Jest zatem, jak najbardziej poprawnym mówić o nim, jako o Serafickim Ojcu czy Serafickim Patriarsze. Otrzymane stygmaty stały się pieczęcią i potwierdzeniem ogromnej miłości brata Franciszka wobec Chrystusa ukrzyżowanego. W pewnym momencie historii chrześcijaństwa Święty z Asyżu postrzegł siebie samego, jako ukrzyżowanego na podobieństwo Serafina (nie na podobieństwo Chrystusa!). Stał się tym, kogo zobaczył, jakby drugim ukrzyżowanym Serafinem, por. W. Block, Franciszek Seraficki, dz. cyt., s. 30-31.

${ }^{29}$ Por. ŻbłF 112-115. 
Kolejną cnotą, symbolizowaną przez parę skrzydeł rozwiniętych do lotu, jest miłość bliźniego. Wyraża się ona w dwojaki sposób: przez słowo Boże i uczynki miłosierne względem ciała:

Dwoma zaś skrzydłami należy latać, celem wypełnienia dwojakiej miłości bliźniego, mianowicie duszę jego karmić słowem Bożym, a ciało podtrzymywać wsparciem doczesnym. Te skrzydła bardzo rzadko się stykają, jako że trudno o kogoś, kto mógłby wypełnić obydwie czynności. Pióra tych skrzydeł to różne uczynki na rzecz bliźniego, służące do udzielania mu rady i pomocy (ŻbłF 114, 14-16).

Trzecia para skrzydeł, która okrywa ciało Serafina, symbolizuje słabość i skruchę. Wprowadza ona chrześcijanina w doświadczenie Bożego miłosierdzia, a dokonuje się to przez ewangeliczny żal za grzechy i pragnienie sprawiedliwości:

Wreszcie, dwoma skrzydłami należy okrywać ciało ogołocone z zasług. Normalnie dokonuje się to wtedy, kiedy człowiek obnażony na skutek grzechu ubiera się z powrotem w niewinność pokuty oraz spowiedzi. Pióra tych skrzydeł to wielorakie uczucia, co rodzą się z żalu za grzechy i z pragnienia sprawiedliwości (żbłF 114, 17-18).

Symboliczne znaczenie sześciu skrzydeł Serafina to dla brata Tomasza z Celano bardzo konkretna praca, jaką może podjąć każdy ochrzczony czerpiąc wzór z pierwszego Stygmatyka na rzecz zdobycia sześciu cnót, symbolicznie przedstawionych przez trzy pary skrzydeł anioła:

- skrzydła ponad głową - czysta intencja i prawe działanie

- skrzydła służące do latania - dwojaka miłość bliźniego

- skrzydła, okrywające ciało- niewinność pokuty i spowiedzi.

Seraficzna miłość i nieustanne pełnienie woli Bożej przybliżyło Franciszka w sposób cudowny do Jezusa, poprzez co stał się on żywym przykładem dla chrześcijan. Jego największe pragnienie, jakie nosił w swym sercu, wypełniło się, kiedy przez miłość zobrazował i wykształcił w sobie Serafina, a przez krzyż i cierpienie zasłużył na dołączenie do najwyższego stopnia duchów anielskich - czytamy w ostatnim paragrafie dziewiątego rozdziału:

To wszystko święty ojciec Franciszek wypełniał jak najdoskonalej. Zobrazował i wykształcił w sobie Serafina. Trwając na krzyżu, zasłużył na dołączenie do najwyższego stopnia duchów. Zawsze bowiem był na krzyżu, nie uchylał się przed 
żadnym trudem i bólem, żeby tylko w sobie i z siebie wypełnić wolę Pana (ŻbłF $115,1-2)^{30}$.

\section{Struktura i ogólna treść traktatu Droga duszy do Boga ${ }^{31}$}

Analogia, jaką stosuje Bonawentura w odniesieniu do skrzydeł Serafina, jest całkiem inna od zaproponowanej przez brata Tomasza z Celano, którą z pewnością Doktor Seraficki musiał znać, biorąc pod uwagę, iż Żywot błogosławionego Franciszka został napisany dwadzieścia lat wcześniej i cieszył się dużą ilością kopii, a więc był „łatwo” dostępny dla zainteresowanych tematem. Autor Itinerarium uczynił z trzech par skrzydeł Serafina fundament dla struktury traktatu, gdzie:

- pierwsza para skrzydeł symbolizuje kontemplacje extra nos (,poza nami”), odkrywając ślady Boga we wszechświecie;

- druga para skrzydeł kieruje się do wnętrza (in nobis), dotykając tego, co w człowieku duchowe, by poznać Boga poprzez obraz (imago), tzn. odnajdując obraz Boży, jaki Stwórca wpisał w osobę ludzką;

- trzecia para skrzydeł supra nos (,ponad nami”) pozwala poznać Boga w Jego istocie dzięki podobieństwu (similitudo) łączącemu człowieka z jego prawzorem.

Bonawentura, tak pisze o podziale swego dzieła we wstępnej części pracy:

Żeby dojść do rozważania pierwszej zasady, która jest najbardziej duchowa i wieczna oraz istnieje ponad nami, należy rozpoczynać od śladu, który jest cielesny, uwarunkowany czasem oraz poza nami [co oznacza wkroczenie na drogę Bożą], wejść następnie do wnętrza swojego ducha, który jest odwiecznym obrazem Boga,

30 „Qui Seraphim imaginem tenuit atque formam, et in cruce perseverans ad sublimium spirituum gradum meruit advolare".

31 Ta część artykułu jest streszczeniem referatu wygłoszonego z okazji Międzynarodowej konferencji poświęconej świętemu Bonawenturze z Bagnoregio zorganizowanej w dniach 1-2 czerwiec 2017 roku przez Instytut Studiów Franciszkańskich, Ośrodek Studiów Franciszkańskich UPJPII w Krakowie, Klasztor Franciszkanów w Krakowie oraz Gminę Miejską Kraków. Por. W. Block, Podróż w głąb Boga samego. Lektura „Drogi duszy do Boga” Bonawentury z Bagnoregio, w: Bonawenturiański sposób myślenia. Pytanie o aktualność (1217-2017), red. R. Kośla, Kraków 2018, s. 265-287. 
duchowym, a zarazem wewnątrz nas [co oznacza wejście w Bożą prawdę], wreszcie trzeba przekroczyć samego siebie i wspinać się ku temu, co wieczne, absolutnie duchowe i ponad nami, kierując wzrok ku pierwszej zasadzie [oznacza to radość z poznawania Boga oraz wielbienie Bożego majestatu] (Itinerarium 1, 2) 32. $^{32}$

Doktor Seraficki raz jeszcze, tym razem na początku pierwszego rozdziału zatytułowanego „medytacja ubogiego na pustyni”"33, wyjaśnia strukturę dzieła, odwołując się tym razem nie do trzech skrzydeł Serafina, ale do trzech dni modlitwy na pustyni (via trium dierum in solitudine). Każdy dzień podzielony jest w sposób symboliczny na trzy medytacje kontemplujące trzy sposoby egzystencji wszystkiego, co istnieje. Przedmiotem medytacji wieczornej jest materialne bytowanie rzeczy będących śladami Boga (vestigia Dei) o określonej cielesności i czasowości. Przedmiotem medytacji porannej jest wnętrze człowieka, w którym odkrywa ona obraz Boga (imago Dei), czyli racjonalność bytów i ich duchową naturę (mają początek, ale nie mają końca). Z kolei medytacja południowa jest refleksją nad ideami wszystkich bytów istniejących w umyśle Bożym (similitudo Dei), czyli medytacją nad „wieczną sztuką” (arte aeterna) ${ }^{34}$ :

32 W podsumowaniu swego dzieła Bonawentura raz jeszcze opisuje strukturę przebytej drogi: „Przeszliśmy więc przez sześć rozważań, jak gdyby po sześciu stopniach autentycznego tronu Salomona, gdzie człowiek napełniony pokojem odpoczywa w uspokojonej duszy (mens) jak w wewnętrznej Jerozolimie; jak gdyby sześć skrzydeł cherubina, za pomocą których dusza prawdziwego kontemplatyka, zalana światłem płynącej z góry mądrości, zdolna jest poderwać się ku górze; jak gdyby wreszcie sześć pierwszych dni, w których dusza ma się ćwiczyć, by na końcu dojść do odpoczynku siódmego dnia. Nasz duch (mens) kontemplował Boga w świecie zewnętrznym, poprzez ślady i w śladach, i w sobie, poprzez obraz i w obrazie, i ponad sobą, dzięki podobieństwu światła, które jaśnieje nad nami, oraz w samymże świetle, o ile to możliwe za życia dla naszego umysłu (mens)" (Itinerarium 7,1).

33 Tytuł wprowadzający do pierwszego rozdziału: speculatio pauperis in deserto („medytacja ubogiego na pustyni”), pominięty niestety w polskim wydaniu, jest bardzo sugestywny, wskazując na fundamenty drogi prowadzącej ku Bogu: wyciszenie, samotność i pokorę.

34 Syn Boży jest najwyższym i najdoskonalszym wyrażeniem mądrości i potęgi Ojca (przez Niego Ojciec wszystko stworzył), dlatego sztukę wieczną Bonawentura przypisuje Słowu, a niekiedy nazywa Je wprost „sztuką Ojca”. Człowiek, będąc obrazem Boga, działa również w sposób wolny i według pewnych ujęć należy przyjąć istnienie sztuki ludzkiej (ars humana) będącej obrazem sztuki wiecznej; por. C. Niezgoda, S. Kafel, Komentarz, w: Święty Bonawentura, Droga duszy do Boga i inne traktaty, dz. cyt., s. 22. 
Zgodnie z tą potrójną drogą, umysł nasz posiada trzy główne ukierunkowania: na rzeczy zewnętrzne (dlatego mówimy o zwierzęcości czy zmysłowości), na własne wnętrze (dlatego mówimy o duchu - spiritus), oraz na to, co jest ponad nim (dlatego mówimy o duchu - mens) (Itinerarium 1,4) ${ }^{35}$.

Każda z medytacji (wieczorna, poranna i południowa) została podzielona na dwa etapy zgodnie z tym, że Serafin posiada trzy pary skrzydeł, po dwa w każdej parze: „Postać sześcioskrzydłego serafina wskazuje na sześć kolejnych oświeceń" (Itinerarium 1, 3). Ostatnim, siódmym etapem duchowej drogi jest mistyczna ekstaza: całkowite zatopienie człowieka w Bogu, które zostało opisane w ostatnim rozdziale dzieła ${ }^{36}$.

\section{a) Medytacja wieczorna - pierwsza para skrzydeł}

Pierwsza para skrzydeł symbolizuje lekturę stworzonego świata. Dokonuje się ona za pośrednictwem zwierciadła (per speculum), bowiem „W rzeczach stworzonych odbija się największa moc, mądrość i dobroć Stworzyciela" (Itinerarium 1, 10), wtedy, gdy zmysły człowieka (wzrok, dotyk, smak, słuch i powonienie) dostrzegają różnorodność i niepowtarzalność stworzonego świata, a następnie rozum odbiera owo bogactwo istnienia jako ślady Boga (vestigia) pozostawione w czasie i w przestrzeni. Z kolei wiara wskazuje, iż istniejący wszechświat miał początek jako stworzony przez Słowo Stwórcy.

Druga refleksja to poznanie w zwierciadle (in speculo). Polega ona na odnajdywaniu Boga w bytach: „w każdym stworzeniu wchodzącym do naszej duszy (mens) poprzez zmysły ciała" (Itinerarium 2,1). Ten sposób poznawania przebiega na trzech poziomach:

- poznawcze ujęcie rzeczy materialnych (apprehensio)

- radość, jaką to poznanie przynosi (oblectatio)

- rozróżnienie-osąd poznanych rzeczy (diiudicatio)

35 Secundum hunc triplicem progressum mens nostra tres habet aspectus principales. Unus est ad corporalia exteriora, secundum quem vocatur animalitas seu sensualitas: alius intra se et in se, secundum quem dicitur spiritus; tertius supra se, secundum quem dicitur mens.

36 Na temat struktury dzieła zob.: V. Ch. Bigi, Scritti Francescani, Bolonia 2017, s. 231-246. 
Wszystkie stworzenia materialnego świata prowadzą człowieka mądrego do Boga. Każde z nich, będąc ze swej natury podobieństwem i obrazem wiecznej mądrości i piękna, staje się dla Bonawentury symbolem, znakiem wskazującym na Stwórcę i odnoszącym do Niego. Mądrość człowieka wyraża się w fakcie, iż potrafi przejść od refleksji i kontemplacji świata do pierwszej Przyczyny każdego istnienia. Żywym przykładem takiej mądrości był właśnie Franciszek z Asyżu. W Legendzie większej dedykowanej osobie błogosławionego Franciszka, Doktor Seraficki tak opisze jego sposób odkrywania Boga:

Aby zaś wszystko pobudzało go do miłości Boga, radował się wszystkimi dziełami
rąk Pańskich i poprzez ich widzialne piękno wznosił się do ożywiającej Przyczyny
i Racji ostatecznej. We wszystkim co piękne, widział Najpiękniejszego; dzięki śla-
dom zostawionym w rzeczach wszędzie znajdował Umiłowanego, ze wszystkiego
robiąc sobie drabinę, po której wstępował na spotkanie Tego, który cały jest godny
pragnienia. Z niesłychanym uczuciem pobożności rozkoszował się ową źródlaną
dobrocią w poszczególnych stworzeniach, jakby w potokach. Słysząc niebiańską
muzykę w harmonii mocy i darów udzielonych im przez Boga, na podobieństwo
proroka Dawida zachęcał je słodko do wielbienia Pana (Legenda większa 1, 6-9).

Życie Franciszka w rozumieniu Bonawentury to nieustanna adoracja i pochwała Stwórcy. O Nim bowiem mówi i na Niego wskazuje otaczający świat, znak, ślad lub symbol odnoszący nieustannie do Dobrego Ojca ${ }^{37}$. Nie tylko Bonawentura, także inne źródła hagiograficzne potwierdzają taką postawę brata Franciszka w przeżywaniu i rozumieniu stworzonego świata: „Z miłości do Tego, który nazywany jest Skałą, gdy wypadło mu iść po skałach, szedł z wielką bojaźnią i szacunkiem” lub „Z miłości

37 W czasie, kiedy Święty z Asyżu tworzył Pieśń słoneczną - jeden z piękniejszych poematów na cześć Stwórcy i jego stworzenia, jaki skomponował człowiek - w całej Europie funkcjonowało wiele prądów myślowych umniejszających to co stworzone i materialne, na rzecz tego co duchowe i wieczne. Człowiek średniowiecza obawiał się kosmosu, przyrody i tego co materialne. Na początku XI wieku pewien angielski kapłan napisał poemat Brut, w którym stwierdza, iż powietrze zamieszkuje wiele istot dobrych, ale jeszcze więcej złych, które będą żyć aż do skończenia świata. Całą przyrodę, a zwłaszcza jej mało dostępne obszary, zamieszkuje szereg demonów, ale są tam też duchy przyjazne człowiekowi, które trzeba oswajać, por. S. Jaromi, Przyroda jako brat i siostra: fenomen XIII wieku, w: Stworzyciel i przyroda w tradycji i myśli europejskiej. Dydaktyka chrześcijańskiej etyki ekologicznej, red. A. Dyduch-Falniowska, Kraków 1999, s. 25-26. 
do Tego, który zechciał dokonać dzieła zbawienia naszego na drzewie krzyża, mawiał również bratu, który wycinał i przygotowywał drzewo na ogień, żeby nigdy nie ścinał całego drzewa, lecz tak przycinał drzewa, by zawsze jakaś część pozostała nienaruszona" (Zwierciadło doskonałości 118, 3-4). Aż po dzień dzisiejszy Franciszkowe postrzeganie mikro- i makrokosmosu jest sposobem widzenia świata wzrokiem nowego człowieka, dla którego realna rzeczywistość nie jest wyłącznie polem działania złego ducha, ale objawieniem się dobroci Boga ${ }^{38}$. Z tego też powodu we wrześniu 1977 roku Międzynarodowe Stowarzyszenie Planning Environmental and Ecological Institute for Quality of Life zwróciło się do watykańskiej Kongregacji do spraw Duchowieństwa z prośbą o ogłoszenie świętego Franciszka patronem ekologów, a kilkadziesiąt lat później, 24 maja 2015 roku, papież Franciszek w encyklice Laudato si raz jeszcze podkreślił ogromny wpływ Serafickiego Ojca na właściwą relację człowieka do przyrody i stworzenia.

\section{b) Medytacja poranna - druga para skrzydeł}

Druga para skrzydeł Serafina ukierunkowuje chrześcijanina zmierzającego ku Bogu na kontemplację swego wnętrza-ducha (intra nos), na lekturę własnej duszy, by w niej dostrzec obraz (imago Dei) błogosławionej Trójcy jaśniejący na duchowym obliczu, niczym w zwierciadle (per speculum) (por. Itinerarium 3, 1). Odwołując się do myśli Augustyna z Hippony, szczególnie do traktatu De trinitate, autor w pierwszej części porannej medytacji podkreśla rolę i znaczenie trzech władz duszy, jakimi są: pamięć, inteligencja i władza wolitywna.

Pamięć (memoriae) jest w stanie zatrzymać w sobie nie tylko rzeczy obecne, cielesne i doczesne, ale także przyszłe, proste i wieczne:

38 Znany duński teolog, W. Visser’t Hooft (†1985), sekretarz generalny Soboru Watykańskiego II, twierdził, iż: „Franciszek przyczynił się do wybuchu prawdziwej rewolucji w relacji człowieka do natury. Wcześniej natura nie miała należytego miejsca w sercu i umyśle człowieka, a chrześcijanie pojmowali doskonałość jako jej «odrzucenie». Wraz z Franciszkiem natura, świat, przyroda zaczęła przemawiać do człowieka językiem zrozumiałym. Człowiek i natura zaczęli prowadzić ze sobą dialog" (W. Visser't Hooft, Dionysos o san Francesco, w: Lettere di Roma, Rzym 1974, s. 3). 
Pamięć zatrzymuje rzeczy przeszłe dzięki przypominaniu, teraźniejsze dzięki przyjęciu, przyszłe dzięki przewidywaniu. Rzeczy proste zatrzymuje jako elementy ilości ciągłych i podzielnych, jak punkt, chwila i jedność, bez których niemożliwe jest pamiętanie czy myślenie o tym, co opiera się na tych elementach. Zasady i aksjomaty wiedzy zatrzymuje zawsze jako wieczne (Itinerarium 3, 2) ${ }^{39}$.

Inteligencja (intellectus) objawia się poprzez pojmowanie nazw, zdań i rozumowań. Nazwy są zrozumiałe dla rozumu, kiedy odpowiadają swym definicjom. Zdania są pojmowane poprawnie przez umysł wtedy, gdy są prawdziwe. W rozumowaniu natomiast wniosek wynika z przesłanek w sposób konieczny.

Najwyższa władza duchowa duszy to władza wolitywna (virtutis electivae). Jej działanie wyraża się poprzez:

- namysł (consilio) - szuka zawsze tego co najlepsze; taka praca zakłada istnienie pojęcia najwyższego dobra wyciśniętego w ludzkim umyśle

- osąd (iudicio) - musi być dokonany na podstawie określonego prawa; jeśli osąd ma być sprawiedliwy, musi odwoływać się do praw Bożych

- pragnienie (desiderio) - kieruje się wyłącznie tylko ku dobru, ku temu, by być szczęśliwym i kochanym.

Konkludując, Bonawentura stwierdza, że trzy władze duchowe, jakie posiada każdy człowiek ${ }^{40}$, jeśli tylko funkcjonują właściwie, wskazują na bliskość Boga: pamięć - prowadzi do wieczności, inteligencja do prawdy, a władza wolitywna - do najwyższego dobra; one doprowadzają

39 „Operatio autem memoriae est retentio et repraesentatio non solum praesentium, corporalium et temporalium, verum etiam succedentium, simplicium et sempiternalium. Retinet namque memoria praeterita per recordationem, praesentia per susceptionem, futura per praevisionem. Retinet etiam simplicia, sicut principia quantitatum continuarum et discretarum, ut punctum, instans et unitatem, sine quibus impossibile est meminisse aut cogitare ea quae principiantur per haec".

40 „A te trzy prawdy - prawda znaków, słów i obyczajów - są trzema działami filozofii, lecz ich istnienia nie wynaleźli filozofowie. Lecz - jak naucza Augustyn - ponieważ istniały już według prawdy, filozofowie dostrzegli je w duszy" (Bonawentura z Bagnoregio, Konferencje o sześciu dniach stworzenia albo oświecenia Kościoła, wyd. synoptyczne tekstu oryginalnego redakcji A oraz B z przekładem polskim, tłum. red. i wst. A. Horowski, Kraków 2008, IV, 2). 
człowieka (homo viator) do samej Trójcy ${ }^{41}$. Stąd też wszystkie dziedziny wiedzy prowadzą do prawdy o Trójcy. Każda jej forma, ponieważ korzysta ze światła, które pochodzi od Boga, jest podporządkowana światłu, jakie w pełni objawiło się w Słowie Wcielonym, i ku niemu prowadzi ${ }^{42}$.

Na następnym poziomie wędrówki homo viator będzie kontemplował Pierwszą Zasadę już nie tylko przechodząc przez siebie, ale pozostając w sobie samym (in nobis). W tego rodzaju poznaniu niezbędne jest pośrednictwo Chrystusa, bowiem niezależnie od tego, w jakiej mierze ktoś został oświecony światłem natury i wiedzy nabytej, powinien wejść w siebie, by tam spotkać Wcielone Słowo, które tylko jest w stanie dać pełną harmonię ludzkiemu wnętrzu. Nawiązując do myśli Pseudo-Dionizego, Bonawentura nazywa ten proces hierarchizacją lub uporządkowaniem ducha ${ }^{43}$. O ile wcześniej postęp nie był możliwy bez odwołania się do ludzkiej wiedzy (trzy rodzaje filozofii), o tyle teraz istotne jest światło płynące z Pisma Świętego, czyli wiedza teologiczna. Dla rozumienia Biblii

${ }^{41}$ W tym przypadku oprócz Traktatu o Trójcy Świętej Bonawentura korzysta także $\mathrm{z}$ traktatu De vera religione.

42 Bonawentura wylicza trzy rodzaje wiedzy-filozofii, jakimi może zajmować się ludzki intelekt: filozofia naturalna dzieli się na metafizykę (bada istotę rzeczy), matematykę (bada liczby i figury) oraz na fizykę (zajmuje się naturą). Filozofia racjonalna obejmuje gramatykę (rodzi mówców), logikę (przestrzega ścisłości w rozumowaniu) i retorykę (zajmuje się umiejętnością przekonywania). Filozofia moralna dzieli się na indywidualną (monasticam) sugerującą wieczność pierwszej zasady, domową (oeconomicam) - wskazującą na intymną więź między Ojcem i Synem, oraz społeczną (politicam) - podkreślającą wspaniałomyślność Ducha Świętego (por. Itinerarium 3, 6).

43 Myśl o uporządkowaniu wnętrza człowieka (hierarchizacja) została rozwinięta w powstałym również w tym samym czasie traktacie Trzy drogi (De triplici via) znanym także jako Ogień miłości: „Każdy rodzaj wiedzy nosi na sobie znamię Trójcy, a zwłaszcza ta, której uczy Pismo święte, dlatego winna ona przedstawiać w sobie ślad Trójcy; z tego powodu Mędrzec (Prz 22, 20) o tej świętej doktrynie mówi, że opisał ją potrójnie, zgodnie z trojakim jej duchowym rozumieniem: moralnym, alegorycznym i anagogicznym. To potrójne rozumienie odpowiada trzem hierarchicznym aktom: oczyszczenia, oświecenia i doskonalenia. Oczyszczenie prowadzi do pokoju, oświecenie do prawdy, doskonalenie do miłości, doskonałe ich osiągnięcie przez duszę uszczęśliwia ją, a za starania o nie otrzymuje ona powiększenie zasługi. Zatem na poznaniu tych trzech dróg polega wiedza całego Pisma świętego, a także zasługa na życie wieczne. Istnieją trzy sposoby ćwiczenia się w tej potrójnej drodze: czytanie i rozważanie, modlitwa oraz kontemplacja" (św. Bonawentura, Trzy drogi albo inaczej ogień miłości, przeł. C. Niezgoda, w: św. Bonawentura, Pisma ascetyczno-mistyczne, Warszawa 1984, s. 15-16). 
Bonawentura korzysta z typowej dla średniowiecza lektury egzegetycznej. Bazuje ona na rozróżnieniu czterech typów znaczeń występujących w Piśmie świętym. Pierwszym etapem jest odróżnienie znaczenia dosłownego tekstu od jego przesłania duchowego. Znaczenie dosłowne pochodzi od ludzkiego autora, zaś za duchowe jest odpowiedzialny Autor boski. Znaczenie duchowe może posiadać trzy sensy: sens alegoryczny, tropologiczny i anagogiczny. Sens alegoryczny ukazuje w sposób ukryty naukę o tajemnicy Chrystusa i Kościoła. Sens tropologiczny odnosi się do życia moralnego człowieka. Sens anagogiczny odwołuje się do życia przyszłego i rzeczywistości nieba, które ukazuje ${ }^{44}$.

Ostatnim zatem krokiem, symbolizowanym przez czwarte skrzydło Serafina jest takie poddanie się działaniu łaski Bożej, by umysł mógł wrócić do tego, co wewnętrzne, a dusza doznała hierarchizacji, czyli uporządkowania według trojakiego sensu Pisma Świętego:

[...] tropologicznego, który oczyszczając, wiedzie do szlachetności życia, alegorycznego, który oświecając, wiedzie do jasności zrozumienia, oraz anagogicznego, który doskonali przez duchowe zachwyty i najsłodsze doznania mądrości (Itinerarium 4,6 ${ }^{45}$.

\section{c) Medytacja południowa - trzecia para skrzydeł}

Trzecia para skrzydeł symbolizuje i odnosi się do lektury obecności Boga we wnętrzu człowieka (similitudo Dei). Ten etap drogi ma miejsce ponad nami (supra nos) i jest możliwy do przebycia dzięki światłu zapalonemu ponad umysłem człowieka. Poznanie dotyczy tego, co w Bogu jest wieczne i niewidzialne. Jedno rozważanie-kontemplacja ma za przedmiot naturę Boga (essentialia Dei), a drugie - właściwości Jego Osób (propia).

${ }^{44}$ Zręczne streszczenie rozumienia owych trzech sensów dał Mikołaj z Lyry (1300), w słowach: Littera gesta docet, quid credas allegoria, moralis quid agas, quo tendas anagogia, (,Sens dosłowny uczy o faktach i czynach; alegoryczny - o przedmiocie wiary; moralny - o tym, co musisz czynić; anagogiczny - o przedmiocie twej nadziei"), por. M. Chmielewski, Czytanie Pisma św., w: Leksykon duchowości katolickiej, red. M. Chmielewski, Lublin-Kraków 2002, s. $175-176$.

45 [...] tropologicam quae purgat ad honestatem vitae; allegoricam, quae illuminat ad claritatem intelligentiae; anagogicam, quae perficit per excessus mentales et sapientiae perceptiones suavissimas, [...]. 
Pierwszy sposób czy stopień kontemplacji przede wszystkim i zasadniczo kieruje się ku oglądaniu samego istnienia i mówi, że pierwszym imieniem Boga (qui est primum nomen Dei) jest „Który jest” (Wj 3, 14). Drugi sposób kontemplowania zwraca wzrok ku samemu dobru i twierdzi, że ono jest pierwszym imieniem Boga (hoc esse primum nomen Dei) (Itinerarium 5, 2) $)^{46}$.

Pierwsza kontemplacja ma za przedmiot czyste istnienie Boga, które jest tak pewne, iż Jego nieistnienie nie może być nawet pomyślane. Istnienie jest początkiem i definitywnym końcem wszystkiego, jest ono bowiem najczystsze i absolutne. Fakt istnienia jest zatem właściwym imieniem Tego, który jest (Ens in quantum Ens).

W dalszej część refleksji autor traktatu przechodzi do drugiego rozważania popołudniowego. Odwołując się do myśli Boecjusza (480-524), wskazuje, iż Bóg jako istniejący od zawsze i sam nieporuszony porusza wszystko ${ }^{47}$. W ten sposób „Ten, który jest” okazuje się być i działać jako „Ten, który jest dobrem” dla dobra i szczęścia stworzenia. Dobro natomiast - jak twierdzi cytowany przez Bonawenturę, Pseudo-Dionizy Areopagita - jest ze swej natury rozlewne (bonum est diffusivum sui) ${ }^{48}$. Dobro stanowi zatem zasadniczy temat dla medytacji o tym, co w Bogu wtórne i pochodne:

Dobro najwyższe jest najbardziej rozlewne, największa zaś rozlewność może mieć miejsce tylko wtedy, gdy jest aktualna i wewnętrzna, substancjalna i osobowa, z natury i z wyboru, wolna i koniecznościowa, ciągła i doskonała (Itinerarium 6, 2).

Owa rozlewność dotyczy przede wszystkim Osób Boskich, co prowadzi Bonawenturę do refleksji nad relacjami w Trójcy, gdzie istnienie Ojca, Syna i Ducha Świętego okazuje się niezbędne, by owo najwyższe dobro mogło zaistnieć:

46 Primus modus primo et principaliter defigit aspectum in ipsum esse, dicens, quod qui est primum nomen Dei. Secundus modus defigit aspectum in ipsum bonum, dicens, hoc esse primum nomen Die (Itinerarium 5, 2).

47 Por. Boecjusz, De consolatione philosophiae III, 9 (PL 63, 759 A).

48 Por. Pseudo-Dionizy Areopagita, De caelesti hierarchia 4,1; De divinis nominibus 4, 1 e 20 (PG 3, 178 C, 694 B, 719 A; PL 122, 1046 B, 1128 D, 1139 C). 
Gdyby więc w najwyższym dobru nie było wiecznego pochodzenia aktualnego i wspótistotowego oraz osoby tak samo godnej jak zasada jej pochodzenia przez zrodzenie i tchnienie; gdyby to pochodzenie nie miało swej wiecznej zasady, która wiecznie pozostaje współzasadą pochodzenia; gdyby przez to kochany nie był współkochany, zrodzony i tchniony, czyli gdyby nie było Ojca, Syna i Ducha Świętego, nie byłoby najwyższego dobra, nie rozlewałoby się ono bowiem najbardziej (Itinerarium 6, 2).

Nie można sobie wyobrazić większego rozlania czy obdarowania, jak wtedy, gdy obdarowujący przekazuje drugiemu całą swoją substancję i naturę ${ }^{49}$. W zakończeniu tego paragrafu Doktor Seraficki proponuje jeden z piękniejszych opisów tego, czym jest wewnętrzne życie Trójcy:

Ponieważ Osoby Trójcy są dobre w stopniu najwyższym, koniecznie musi je znamionować maksymalna tendencja do udzielania się; z maksymalnej tendencji do udzielania się wynika maksymalna współistotność, a z maksymalnej współistotności maksymalne podobieństwo, z nich - maksymalna równość, a przez to maksymalna współwieczność, ze wszystkiego zaś, co zostało powiedziane, maksymalna wewnętrzna wspólnota życia. Ona to sprawia, że jedna osoba jest koniecznościowo w drugiej dzięki maksymalnemu współprzenikaniu się, jedna działa z drugą na skutek absolutnej niepodzielności substancji, mocy i działań Trójcy Przenajświętszej (Itinerarium 6, 2) ${ }^{50}$.

Dopełnieniem tej medytacji jest refleksja nad znaczeniem osoby Wcielonego Boga, bowiem Trójcę Przenajświętszą można poznać i rozważać tylko w kluczu chrystologicznym. Bonawentura zwraca się tutaj i wykorzystuje kolejny symbol, jakim jest obraz dwu cherubinów z Księgi Wyjścia (Wj 25,20). Pierwszy cherubin ukierunkowuje na medytację o istocie

49 Ta myśl jeszcze lepiej została przedstawiona w Quaestiones de mysterio Trinitatis (q. 8, ad 7), gdzie Bonawentura stwierdza (tekst łaciński lepiej oddaje myśl Bonawentury, dlatego odwołuję się do niego), że plenitudo fontalis Boga Ojca jest wyrazem jego primitas, bowiem „Ojciec rodzi Syna, i poprzez Syna i wraz z Nim, rodzi Ducha Świętego, w ten sposób Bóg Ojciec poprzez Syna i z Duchem Świętym jest przyczyną wszystkich rzeczy stworzonych". ${ }^{50}$ Tekst łaciński lepiej oddaje myśl Bonawentury: „In quibus necesse est propter summam bonitatem esse summam communicabilitatem, et ex summa communicabilitate summam consubstantialitatem, et ex summa consubstantialitate summam configurabilitatem, et ex his summam coaequalitatem, ac per hoc summam coaeternitatem, atque ex omnibus praedictis summam cointimitatem, qua unus est in altero necessario per summam circumincessionem et unus operatur cum alio per omnimodam indivisionem substantiae et virtutis et operationis ipsius beatissimae Trinitatis". 
Bożej w osobie Chrystusa, gdzie to, co wieczne złączyło się ze śmiertelnym człowiekiem, to co wciąż aktualne z tym, co dawno minęło, a to, co najdoskonalsze i nieskończone, ze słabym i małym (por. Itinerarium 6, 5). Postać drugiego cherubina pomaga Bonawenturze w refleksji nad właściwościami Osób Boskich: „kiedy to w nieustannym akcie miłości Syn zostaje posłany od Ojca, a Duch Święty od obu, mimo że zawsze z nimi pozostaje i nigdy ich nie opuszcza" (Itinerarium 6, 6). W tym miejscu bonawenturiańskie speculatio Christi osiąga kulminację, tak bowiem jak w szóstym dniu w człowieku stworzonym na obraz Boga akt stwórczy osiągnął pełnię, tak w szóstym rozważaniu o roli i osobie Jezusa Chrystusa w poznawaniu tajemnicy Boga Trójjedynego umysł dosięga szczytu oczyszczenia i doskonałości iluminacji:

Spójrz na przebłagalnię i podziwiaj. W Chrystusie osobowe zjednoczenie spotkało się z troistością substancji i dwoistością natur, doskonała harmonia wewnętrzna stoi w zgodzie z dwoma wolami, współorzekanie przymiotów Boskich i ludzkich nie sprzeciwia się ich pluralizmowi, jedność adoracji harmonizuje z wielością przymiotów godnych uwielbienia, jedno wynoszenie ponad wszystko pozostaje w zgodzie z mnóstwem tytułów godności, a jedne rządy schodzą się z niejedną władzą (Itinerarium 6, 6) ${ }^{51}$.

Schematycznie przebytą do tej pory drogę czyli zaproponowaną przez Bonawenturę strukturę, opierającą się na trzech parach skrzydeł Serafina, można przedstawić następująco:

51 „[...], respice in propitiatorium et mirare, quia in Christo stat personalis unio cum trinitate substantiarum et naturarum dualitate; stat omnimoda consensio cum pluralitate voluntatum, stat Dei et hominis compraedicatio cum pluralitate proprietatum, stat coadoratio cum pluralitate nobilitatum, stat coexaltatio super omnia cum pluralitate dignitatum, stat condominatio cum pluralitate potestatum". 


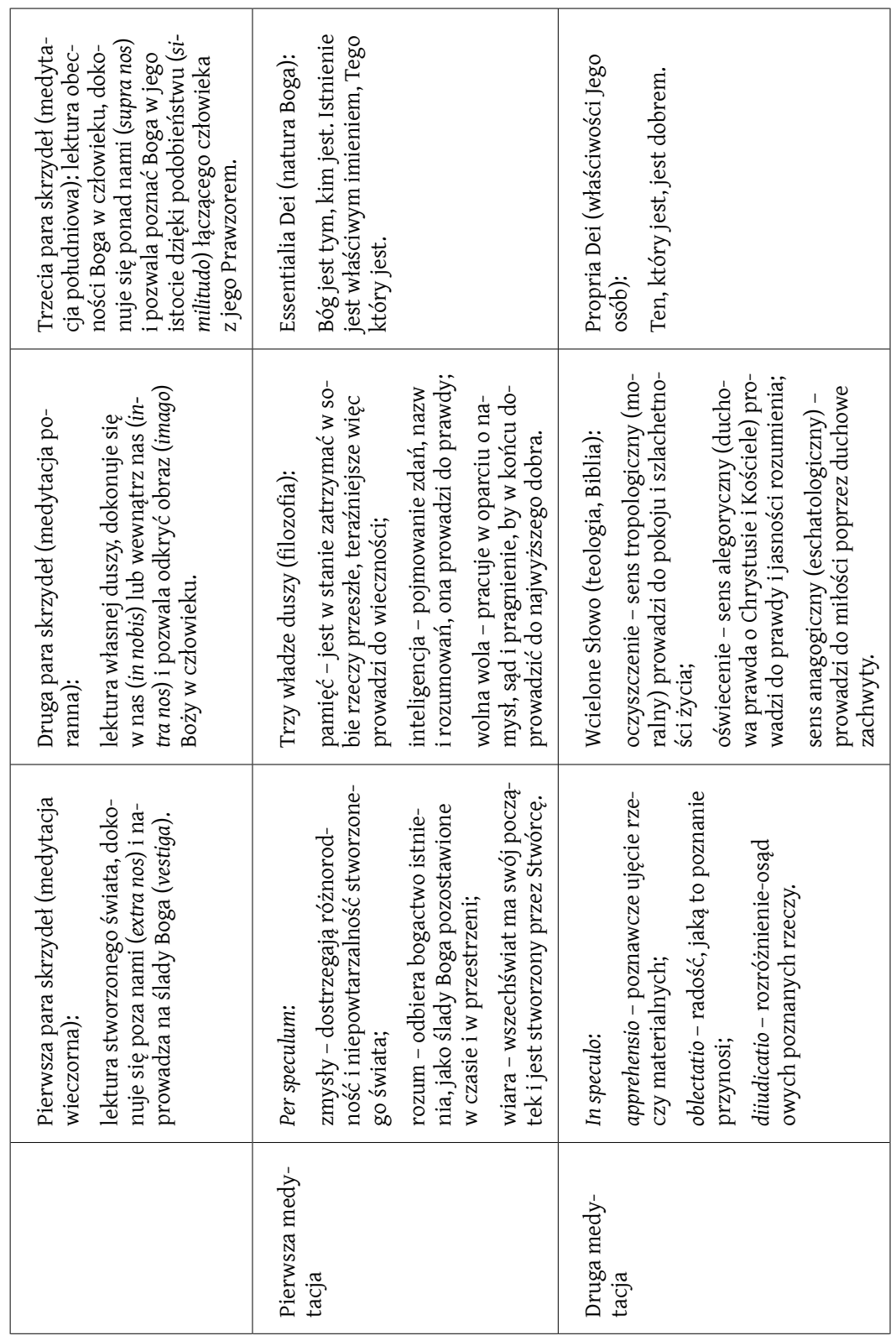




\section{d) Etap siódmy - duchowa i mistyczna ekstaza}

Ostatni etap Itinerarium ma swe uzasadnienie w odpoczynku Boga po sześciu dniach stwarzania. Bonawentura na tym etapie drogi nie odwołuje się już więcej do symbolu skrzydeł Serafina. Aktywność człowieka ustępuje teraz na rzecz pasywności i całkowitemu poddaniu się działaniu Bożej łaski. Na wzór spoczynku Stwórcy po sześciu rozważaniach człowiek zostaje zaproszony do duchowej i mistycznej ekstazy, w której intelekt doznaje ukojenia, a pragnienia całkowicie pogrążają się w Bogu. Aby tam dotrzeć, konieczne jest pośrednictwo Chrystusa, który poprzez śmierć i zmartwychwstanie, tego kto się w Niego wpatruje i ku Niemu się zwraca, przeprowadza do duchowej i mistycznej ekstazy:

Kto zdecydowanie i całkowicie zwraca się ku Chrystusowi-Przebłagalni, kto z wiarą, nadzieją i miłością, pobożnością, podziwem, radością, czcią, pochwałą i wysławianiem wpatrzy się w Niego, jak wisi na krzyżu, ten dokonuje wraz z Nim paschy, czyli przejścia (por. Wj 12,11), by przez drzewo krzyża przejść przez Morze Czerwone, z Egiptu wkroczyć na pustynię, kosztować smaku ukrytej manny (por. Wj 16, 15) (Itinerarium 7, 2).

Takie właśnie doświadczenie stało się udziałem Franciszka z Asyżu, kiedy na górze Alwerni w ekstazie kontemplacji (in excessu contemplationis) ujrzał Serafina o sześciu skrzydłach przybitego do krzyża (por. Itinerarium 7, 3). To właśnie na tej górze dokonał się Franciszkowy exodus, przejście (transitus):

[...] przeszedł przez ekstazę kontemplacji i stał się przykładem kontemplacji doskonałej, jak przedtem był przykładem działania (por. Itinerarium 7,3$)^{52}$.

W tym miejscu, zbliżając się do końca swych rozważań ${ }^{53}$, Doktor Seraficki powraca do punktu wyjścia swych rozważań, powołując się

${ }^{52},[. .$.$] , transiit per contemplationis excessum; et positus est in exemplum perfectae$ contemplationis; sicut prius fuerat actionis, [...]".

${ }^{53}$ Z niezrozumiałych względów polskie wydanie Drogi duszy do Boga kończy się na piątym punkcie siódmego rozdziału. W języku łacińskim jest jeszcze punkt szósty, który kończy całe dzieło. Oto jego treść: „I jeśli potem się pytasz, jak to się stanie, stawiaj pytanie łasce, a nie doktrynie; pragnieniu, a nie inteligencji; łzom rodzącym się na modlitwie, a nie studium i lekturze; oblubieńcowi, a nie nauczycielowi; Bogu, a nie człowiekowi; ciemności, a nie 
na świadectwo brata Leona, który był obecny na górze Alwerni i opowiedział zarówno Bonawenturze jak i innym braciom o tym, co tam się wydarzyło:

To właśnie ujrzał święty Franciszek, gdy na wysokiej górze, w ekstazie kontemplacji, objawił mu się sześcioskrzydły serafin przybity do krzyża (tutaj rozmyślałem o tym, co napisałem, tutaj również mnie oraz wielu innym opowiedział o tym brat, który mu wówczas towarzyszył) (Itinerarium 7,3).

Bonawentura jest przekonany, iż droga, jaką przeszedł Franciszek jest jedyna w swoim rodzaju, wzorcowa i niemal nie do powtórzenia. Przez przykład Franciszka chce zachęcić on jednak wszystkich chrześcijan do posiadania tych samych pragnień i otwartości na działanie Ducha Świętego:

Jest to coś mistycznego i okrytego głęboką tajemnicą, której nikt nie zna, jeśli mu jej nie odsłoniono (por. Ap 2,17). Nie otrzymuje tego nikt, kto nie pragnie, a pragnie tylko ten, $w$ czyje wnętrze rzuca płomień Duch Święty posłany przez Chrystusa. Dlatego Apostoł mówi, że tę mistyczną mądrość objawia Duch Święty (por. 1 Kor 2,10; $1 \mathrm{~J} 2,20-27$ ) (Itinerarium 7, 4).

\footnotetext{
światłości, ani światłu; zwróć się ku ogniu, który wszystko rozpala i który z pędem skruchy i uczuciem jak najgorętszym ukierunkowuje na Boga. To Bóg jest tym ogniem i jego «piec jest w Jerozolimie» (Iz 31,9). Chrystus rozpala ten ogień poprzez uderzenie miłości płynące z Jego najgorętszej męki, odczuwa go ten tylko, który mówi «dusza moja wybrała uduszenie, a śmierć - moje członki» (Hi 7,15). Kto kocha śmierć, może widzieć Boga, ponieważ jest bez wątpienia prawdziwe to stwierdzenie: «żaden człowiek nie może oglądać mojego oblicza i pozostać przy życiu» (Wj 33,20). Umierajmy więc, i wstępujmy do ciemności; nakażmy zamilknąć naszym troskom, pragnieniom, żywym obrazom, przejdźmy wraz z Chrystusem Ukrzyżowanym «od tego świata do Ojca» (J 13,1), abyśmy, kiedy zostanie nam ukazany Ojciec mogli powiedzieć wraz z Filipem «to nam wystarczy» (J 14,8); słysząc z Pawłem «wystarczy ci mojej łaski» (2 Kor 12,9); wykrzykiwać radośnie z Dawidem «Niszczeje moje ciało i serce, Bóg jest opoką mego serca i mym udziałem na wieki» (Ps 73,26). «Błogosławiony Pan, Bóg Izraela, od wieków na wieki! A cały lud niech powie: Amen! Alleluja!» (Ps 106, 48)” (tłum. własne).
} 


\section{Podsumowanie}

Traktat Droga duszy do Boga powstał pod wpływem głębokiego, wewnętrznego przeżycia, jakiego doświadczył jego autor na górze Alwerni. Struktura i treść tego dzieła w pełni odzwierciedla atmosferę góry stygmatów. Sześć skrzydeł Serafina posłużyły Bonawenturze za punkt odniesienia do budowy traktatu, a duchowe doświadczenie brata Franciszka stało się źródłem co do jego treści. Pielgrzymowanie człowieka ku Bogu przebiega przez sześć etapów, by potem na samym końcu drogi, przejść do ostatniego, jakim jest odpoczynek w Trójcy i czysta Jej kontemplacja. By przebycie tej drogi było możliwe, podejmujący ją chrześcijanin musi zdawać sobie sprawę ze swej słabości i nędzy. Małość człowieka to skutek grzechu pierworodnego, który podwójnie skaził ludzką naturę: „umysł ignorancją a ciało pożądliwością” (Itinerarium 1, 7). Ogarnięty mocną wolą dojścia do Boga i odnalezienia się w Nim, chrześcijanin powinien być świadomy, że jego postęp zależy wyłącznie od łaski Bożej, z którą trzeba mu współdziałać poprzez nieustanną i ufną modlitwę oraz zatopienie $\mathrm{w}$ medytacji Pisma świętego. W tej duchowej podróży istotną rolę spełnia Słowo Wcielone, bowiem „płomienna miłość Ukrzyżowanego" (Itinerarium Prolog 3) jest jedyną drogą, po której należy kroczyć. Natomiast podstawowym narzędziem pozwalającym człowiekowi rozpoznawać i rozważać tajemnice Boga, są władze duszy i intelektu umożliwiające przejście od tego, co zewnętrzne i czasowe do tego co wewnętrzne i wieczne. Traktat powstały na górze Alwerni ubogacił myśl średniowiecza i duchowość chrześcijańską franciszkańskim spojrzeniem na dzieło stworzenia, gdzie poprzez refleksję nad tym co zostało uczynione, niewidzialne przymioty Boga mogą stać się widoczne i doświadczalne dla tych, którzy chcą Go we wszystkim błogosławić i kochać; bowiem pragną przejść z ciemności niewiedzy do mądrości istnienia i przedziwnego światła Bożego (por. Itinerarium 2, 13). 


\section{Summary}

\section{Doświadczenie Alwerni źródłem powstania Drogi duszy do Boga}

\section{św. Bonawentury z Bagnoregio}

Struktura i treść Droga duszy do Boga dzieła w pełni odzwierciedla atmosferę stygmatyzacji Franciszka. Obraz sześciu skrzydeł serafina posłużyły Bonawenturze za punkt odniesienia do budowy traktatu, a duchowe doświadczenie brata Franciszka stało się źródłem co do jego treści. Pielgrzymowanie człowieka ku Bogu przebiega przez sześć etapów, by potem na samym końcu drogi, przejść do ostatniego, jakim jest odpoczynek w Trójcy i czysta Jej kontemplacja. W tej duchowej podróży istotną rolę spełnia Słowo Wcielone. Natomiast podstawowym narzędziem pozwalającym człowiekowi rozpoznawać i rozważać tajemnice Boga, są władze duszy i intelektu.

Słowa klucze: doświadczenie Alwerni, Droga duszy do Boga, św. Bonawentura z Bagnoregio

Alwernia's experience as the source for the creation of The soul's journey into God, St. Bonaventure of Bagnoregio

Structure and content The soul'sjourney into God work fully reflects the atmosphere of stigmatization of Francis. The image of the six wings of seraphim served as a point of reference for Bonaventure for the construction of the treatise, and St. Francis' spiritual experience became a source of its content. The pilgrimage of man to God goes through six stages, and then, at the very end of the road, goes to the last, which is rest in the Trinity and pure contemplation. In this spiritual journey, the Incarnate Word fulfills an important role. However, the basic tool that allows man to recognize and meditate on the mysteries of God are the authorities of the soul and the intellect.

Keywords: Alwernia's experience, The soul's journey into God, St. Bonaventure of Bagnoregio

\section{Bibliografia}

Bartoli Langeli A., Gli autografi di frate Francesco e di frate Leone, Turnhout 2000, 95 (Corpus Christanorum. Autographa Medii Aeui, V).

Bigi V. Ch., Scritti Francescani, Bolonia 2017.

Block W., Franciszek i jego bracia, tłum. K. Kreczko, Kraków 2017.

Block W., Franciszek Seraficki, Kraków 2013 (Biblioteka Instytutu Studiów Franciszkańskich, 14). 
Bonawentura z Bagnoregio, Konferencje o sześciu dniach stworzenia albo oświecenia Kościoła, wyd. synoptyczne tekstu oryginalnego redakcji A oraz B z przekładem polskim, tłum. red. i wst. A. Horowski, Kraków 2008.

Chmielewski M., Czytanie Pisma św., w: Leksykon duchowości katolickiej, red. M. Chmielewski, Lublin-Kraków 2002, s. 175-176.

Corvino F., Bonaventura da Bagnoregio, francescano e pensatore, Bari 2006.

Fontes Franciscani, red. E. Menestò, S. Brufani i in., Assisi 1995.

Frugoni C., Francesco e l'invenzione delle stimmate: una storia per parole e immagini fino a Bonaventura e Giotto, Torino 1993.

Jaromi S., Przyroda jako brat i siostra: fenomen XIII wieku, w: Stworzyciel i przyroda $w$ tradycji i myśli europejskiej. Dydaktyka chrześcijańskiej etyki ekologicznej, red. A. Dyduch-Falniowska, Kraków 1999, s. 25-26.

Longpré E., Bonaventure, w: Dictionnaire d'Histoire et de Geographie Ecclesiastiaues, vol. 9, ed. A. Baudrillart, A. de Meyer, R. Aubert, Paris 1937, col. 756.

Menestò E., Leone e i compagni di Assisi, w: I compagni di Francesco e la prima generazione minoritica, Atti del XIX Convegno internazionale della S.I.S.F (Assisi, 17-19 ottobre 1991), a cura E. Menestò, Spoleto 1992, s. 44-51.

Miccoli G., Dall'agiografia alla storia: considerazioni sulle prime biografie francescane come fonti storiche, w: Francesco d'Assisi. Realta e memoria di un esperienza cristiana, a cura di G. Miccoli, Torino 1991.

Miccoli G., Francesco d'Assisi. Memoria, storia e storiografia Milano 2010 (Edizioni Biblioteca Francescana, 12).

Niezgoda C., Kafel S., Komentarz, w: Święty Bonawentura, Droga duszy do Boga i inne traktaty, przeł. C. Niezgoda, S. Kafel, Poznań 2001, s. 22.

S. Bonaventurae, Itinerarium mentis in Deum, w: S. Bonawenturae, Opuscula varia. Theologica, t. 5, Quaracchi 1891, s. 293-316; przekład polski: Święty Bonawentura, Droga duszy do Boga i inne traktaty, przeł. C. Niezgoda, S. Kafel, Poznań 2001.

S. Bonaventurae, Opera omnia..., vol. 8: Opuscula varia ad theologiam mysticam et res Ordinis Fratrum Minorum spectantia, edita a patribus Colegii S. Bonaventurae, Quaracchi $1898,1-229$.

S. Bonaventurae, Decem opuscula ad theologiam mysticam spectantia, Quaracchi 1896, $1965^{5}$.

Scritti di Francesco d'Assisi, red. C. Paolazzi, Grottaferrata 2009.

św. Bonawentura, Pisma ascetyczno-mistyczne, przeł. C. Niezgoda i in., Warszawa 1984.

Visser't Hooft W., Lettere di Roma, Rzym 1974. 